\title{
Conceptualizations of suicide through time and socio-economic factors: a historical mini-review
}

\author{
P. Solano ${ }^{1,2, *}$, E. Pizzorno ${ }^{3}$, M. Pompili ${ }^{4}$, G. Serafini ${ }^{1,2}$ and M. Amore ${ }^{1,2}$ \\ ${ }^{1}$ Department of Neuroscience, Rehabilitation, Ophthalmology, Genetics, Maternal and Child Health (DINOGMI), Section of Psychiatry, University of Genoa, \\ Genoa, Italy \\ 2 Pav.A, San Martino Hospital, Genoa, Italy \\ ${ }^{3}$ Legal Medicine and Forensic Pathologist, Private Practice, Via Zamperini 1, Genoa, Italy \\ ${ }^{4}$ Department of Neurosciences, Mental Health and Sensory Function, Suicide Prevention Center, Sant'Andrea Hospital, Sapienza University of Rome, Rome, Italy
}

Objectives. Suicide is a complex phenomenon determined by the interplay of an articulated network of factors including socio-economic factors which have a decisive role. This paper investigates the development of the modern conceptualization of suicide in Europe, its sociological understandings and its intertwinement with economic cycles throughout time.

Methods. MEDLINE, SCHOLAR, EMBASE using the keywords 'socioeconomic factors AND suicide'; 'economic cycles AND suicide'; 'history AND suicide' without timeframe limitations. Moreover, journal-by-journal search in journals of related areas was performed.

Results. In total, 51 historical studies focusing on the subjects in European countries were included. Three main areas arose: (a) development of the conceptualization of suicide over time; (b) sociological understandings of suicide according to the structure of society and its economy of power; (c) economic theories explaining the intertwinement of economic cycles and suicides.

Conclusions. Suicide is a deeply human phenomenon inescapably linked to and grounded in society and economic cycles. Understandings from the past show the importance of accurate analysis of socio-economic contexts that shape societies together with man's own sense of self in order to organize multi-layered tangible and intangible support strategies to better understand and prevent suicide in this day and age.

Received 19 December 2016; Revised 11 September 2017; Accepted 13 September 2017; First published online 18 October 2017

Key words: Economic cycles and suicide, history of suicide, socio-economic factors and suicide, sociology and suicide, suicide.

\section{Introduction}

Changing attitudes to suicide are as complex and variable as the very complicated social and cultural systems in which they existed (MacDonald, 1995) since suicide often results from a complex interplay of socio-economic and cultural factors, which cannot be considered separately. However, man's idea of taking his own life has always been fraught with doubt and ambivalence leading to the coexistence of different perceptions and conceptualizations of suicide over time. In this paper, we focus on European countries because of the vast differences in culture found elsewhere, such as Asian and Arabic cultures. This means that the understandings presented in this paper cannot be extended to other cultures that are characterized by different structures, history and systems that would require specific investigation.

* Address for correspondence: P. Solano, M.D., Psychiatrist, Ph.D. Student, Department of Neuroscience, Rehabilitation, Ophthalmology, Genetics, Maternal and Child Health (DINOGMI), Section of Psychiatry, University of Genoa, Genoa, Italy.

(Email: paola.solano@alice)
The history of the conceptualization of suicide is characterized by significant changes that led to the development and establishment of its current understanding. For instance, suicide passed from being conceived as a crime against society and nature in Ancient Greece (Preti \& Miotto, 2005) and Rome (Farberow, 1975) to be one of the most severe crimes against God, akin to homicide, according to Christianity (Aquinas, 2006). However, these understandings coexisted with contrasting conceptualizations, such as those put forward by the Stoics and certain Latin authors, that valued man's individuality and human freedom and linked suicide to those ideals. Moreover, the first reports of medical explanations of suicides, that is that drew a link between suicide and altered states of mind or other medical conditions, were put forward along with supernatural ones and date back to Ancient Greece (Preti \& Miotto, 2005). The intertwinement of these opposed conceptualizations heralds subsequent developments that took place between the Middle Ages and the 18th century when medical explanations of suicides finally prevailed. 
Nevertheless, contemporary understandings of suicide are far from being clear-cut. Suicide victims were denied religious funerals and burials until the Second Vatican Council in 1962 when the medical explanation for suicide was emphasized by stating that 'grave psychological disturbances, anguish, grave fear of hardship, suffering or torture can diminish the responsibility of the one committing suicide' (Catholic Church, 1992: paragraph 2282). Other Christian confessions developed similar formulae that included the medical explanation of suicide in their catechism and allowed religious funerals for suicide victims. Despite these recent developments and the current establishment of medical understandings of suicide evidence shows the presence of judgmental conceptualizations and attitudes towards suicide mainly due to religious conceptualizations even in contemporary society (Segal et al. 2004; Colucci \& Martin, 2008; Stack \& Kposowa, 2011; McCormack et al. 2012).

Society, as is well known, strongly influences man's own sense of self and the way he perceives himself in the world together with his wishes and needs. Murray (1998) in Explorations in Personality identified some psychological human basic needs, that if frustrated provoke intense psychic pain involved in suicide. Furthermore, factors such as mental illness may influence the role subjects play in society and how they relate to it together with their working capacity and economic status. These understandings are fostered by a large number of studies suggesting that mental illness plays a pivotal role in mediating the association between unemployment and suicide risk (Lundin et al. 2010) as do public health policies (Stuckler et al. 2009).

The current economic crisis has been positively related to suicide rates by several studies (Stuckler et al. 2009; De Vogli et al. 2012), though it is unclear whether economic downturns and unemployment may represent causal factors for suicide (Hawton \& Van Heeringen, 2009; Luo et al. 2011; Innamorati et al. 2012; Solano et al. 2012). A number of studies demonstrate that European countries with large fiscal adjustments are notably affected by increasing suicide rates (Stuckler et al. 2011; Karanikolos et al. 2013; Breuer, 2015) although specific investigations in some countries fail to confirm these findings. For instance, a causal increase of suicide rates in Greece due to the current economic crises has been reported (Economou et al. 2012; Karanikolos et al. 2013; Kentikelenis et al. 2014) but these findings were not confirmed by other authors (Polyzos, 2012; Fountoulakis et al. 2013). Similarly, Neumayer (2004) and Andres (2005) challenged previous findings that unemployment positively affects suicide in a panel of European countries after controlling for country-specific trends. In the same vein, Pompili et al. (2011) suggested that Italian regional suicide rates were positively associated with employment rates and that regions with higher economic status have higher suicide rates. The different results can be partly due to the use of aggregated data for the analysis (Breuer, 2015) or methodological weaknesses (Andres, 2005), though the relationship between suicide and economic crises still remains an open question involving different sociological and cultural factors.

However, these understandings result from the development of an integrated conceptualization of suicide which gradually began to be considered both psychiatric and sociological matters. This paper examines:

(a) The process that led to the modern conceptualization of suicide together with the changing attitude towards it.

(b) The sociological understandings of suicide throughout time.

(c) The economic theories developed throughout time to understand the relationship between suicide and economic cycles.

\section{Material and methods}

Included studies were retrieved through a two-step search and examination process. First, articles for consideration were retrieved using an extensive literature search through the search terms 'socioeconomic factors AND suicide'; 'economic cycles AND suicide'; 'history' AND 'suicide' in MEDLINE, EMBASE and SCHOLAR without timeframe limitations because of the targeted domain. This produced over 500 studies that were carefully examined one-by-one in order to identify historical papers concerning European countries. Non-historical papers and studies concerning extra-European countries were not included in order to focus better on the subject and keep cultural comparability. In total, 48 historical studies on the subject in European countries remained and were examined for possible inclusion. However, six of these papers were not included in the final study because three papers simply reviewed previous conceptualizations and understandings without adding any further knowledge; two papers did not focus specifically on suicide and suicide theories and one study investigated suicide from religious perspectives that are beyond the scopes of this review. This led to the inclusion of 42 studies. Second, additional titles of papers and books were obtained from the bibliographies of the included articles, and from a journal-by-journal search for journals in related areas, that is history, philosophy, economy and sociology, that we suspected most frequently publish articles in the targeted domain. 
This strategy was adopted to minimize the possibility of overlooking studies that may not yet have been included in computerized databases. From this search, six more included sources were retrieved (Burrows, 1828; Rosen, 1971; Taylor, 1989; Rabinow \& Rose, 2003; Aquinas, 2006; Barbagli, 2009). In the end, 51 studies were included.

\section{Suicide and sociological factors: from crime to mental illness}

Attitudes towards suicide varied during man's history as suicide, from being one of the most severe crimes against God, Law and Nature, became an extreme act of desperation resulting from the sufferings of mental disorders. Socrates, for example, forbade his disciples from committing suicide except under extreme circumstances and both Plato and Aristoteles considered suicide as an act against an obligation to society. The Stoics, however, thought such a decision as part of human freedom. Furthermore, Ancient Greeks expressed the concept of self-killing using a single word connected to a specific method of carrying out the act which is 'autosfaghe' meaning 'He who is slain by himself' as used in Sophocles' Ajax (Lloyd-Jones, 1994) and 'autokeires' meaning 'those who kill themselves' as used in Euripides's Phoenician Women (Kovacs, 2002). Furthermore, according to the Suida, a scholarly encyclopedia on ancient Greece written at the Court of Byzantium, some verbs meaning 'to hang oneself' were used too, implying 'hanging with the aim of being killed by oneself' as in Homer's Odyssey (Preti \& Miotto, 2005).

In ancient Rome, there were different conceptualizations of self-accomplished death. Indeed, Roman law intended suicide as a crime punishable by the requisition of the victim's possessions (Farberow, 1975). However, many Latin authors consider suicide to be a very solemn, detached, unemotional act due to relational, philosophical or political matters such as in the case of Cato Uticensis and Thrasea Paetus in Tacitus's writings (Hill, 2004). This kind of suicide that concerns public figures and members of the aristocracy was called 'Romana Mors.' However, these representations of death have been deemed unrepresentative of truth and even defined unreal by other authors (Alvarez, 2002).

Among the Hebrews, though suicide was infrequently mentioned in the Old Testament, the first formal prohibition may be found when Josephus, in the 1st century $\mathrm{AD}$, forbade his army from committing suicide following their defeat by the Romans (Churchill, 1994; Crone, 1996). Christianity, in light of the example set by Judas, condemned suicide. Augustine of Hippo (2008) formalized this thought in the light of the Sixth Commandment giving no excuses for suicide and, later, Thomas Aquinas considered suicide as against the inclination towards self-preservation, against one's duties towards society and against God's prerogatives as creator of man (Aquinas, 2006). To address suicide, circumlocutions such as 'self-killing' and 'self-homicide' which added a judgmental nuance highlighting the link suicide had with homicide, were used. Augustine of Hippo's conceptualization, adopted by the Church till the 16th century, classified both suicide and homicide under the heading crimen homicidi and suicide victims as well as killers as homicida (Augustine of Hippo, 410 AD). Even from a legal perspective suicide was considered no less severe than homicide (Marsh, 2010).

The word 'suicide' was used for the first time in the 17th century (Shneidman, 1985) in Thomas Browne's Religio Medici. Until that time 'men's underlying moral conceptions were not at the stage of needing a word for so a specific definition, a definition founded, that is, on a particular compound of intention and act' (Murray, 1998: 39-40). The introduction of the word 'suicide' is intertwined with the sociological developments of the time, in particular with the change in the conception of the human being, which acquired his own 'interiority' apart from the 'exteriority' of the world (Taylor, 1989; Strozier, 2002; Martin \& Barresi, 2006). This led to a re-conceptualization of suicide that deeply differed from its understandings in Ancient Times despite its secular perspective.

Furthermore, the 'secularization of suicide,' which believed suicide not to be due to supernatural forces but to man's will, started to develop in Europe at the beginning of the 17th century. For instance, the process of secularization began by considering suicide from an existential perspective - such as put forward by Hume in Essays on suicide and the immortality of the soul - that was later extended to socio-economic understandings. Interestingly, the first sources of the process of secularization of suicide developed in England and led to a gradual decrease in supernatural explanations of the phenomena and the development of a more rational and scientific approach which was favored by the spreading of Enlightenment theories. Overall, suicide became to be understood as the result of a rational choice mostly related to mental disorders (Rosen, 1971; Brown, 2001; Healy, 2006; Houston, 2010). For instance, Robert Burton formalized this scientific perspective of suicide together with its link with mental illness in his Anatomy of Melancholy (written in 1621) where he considered self-murder as consequent to melancholia that, according to him, was due to the decay of the body (Rosen, 1971).

Starting from the 11th century England, when suicide occurred, the act was judged by the local 
Table 1. Transcriptions of verdicts from the Eyre rolls, England

Felo de se

'William de Wedmore, vicar of Chryriton hanged himself in his own home in the same village. The verdict was suicide. And Walter de Wedmore and John his brother(s) buried the said William without view of the coroner and took his chattels, value $34 \mathrm{~s}$ so they are to be arrested. Afterwards they came to court and the sheriff let them go.' (Eyre of Sommerset, 1280)

'A certain Richard, son of Sibill gratis drowned himself in a pit at Marshton St Lawrence. No one is suspected. Judgment felonious suicide. Chattels 6 s 2d.' (Eyre of Northamptonshire, 1329)
Non compos mentis

'William la Emeyse of his vill, suffering from an acute fever which took away his senses, got up at night, entered the water of Kentford and drowned himself. The jury was asked if he did this feloniously and said no, he did this through his illness. The verdict was an accident.' (Eyre of Hereford, 1292)

'Thomas, son of Henry Robekyn of Brandon, in a frenzy (habens frenesium) cut off his left foot with an axe and then his left hand in the house of the said Henry, his father, in Brandon, and the following night he died from this. The first finder and four neighbours came and are not suspected. The jury, asked if they suspected anyone else of this death say no and say that the said Thomas straight after the deed came to his senses (reddit ad sensum proprium) and had the last rites of the church before he died. So the deed was done through the loss of sense and not feloniously. So the judgment is accident.' (Eyre of Norfolk, 1286)

The verdict from the Eyre of Sommerset shows the attempts of the relatives to conceal the suicide in order to avoid the forfeiture. The verdict from the Eyre of Hereford shows how the effects of physical illnesses were considered responsible for mental alterations along with mental illnesses (Adapted from Seabourne \& Seabourne, 2001).

coroner who examined the body and gathered a jury to return a verdict which could be either felo de se (i.e. 'felon of himself') - thus guilty of self-murder - or non compos mentis (i.e. 'not sound of mind'), thus innocent of the crime (see Table 1). However, these two possible verdicts express opposite co-existing attitudes and conceptualizations of suicidal acts. For instance, the 'felo de se' verdict implies that the victim was deemed mentally and physically sane, 'in possession of his right reason and exhibiting at the moment of killing himself the greatest calmness, coolness, and selfpossession' (Royal, 1850: 27). Hence, no disruptive condition was suspected and the suicide was considered and judged as a crime. On the other hand, the verdict 'non compos mentis' was given when the coroner suspected or had evidence of the presence of mental or physical diseases that could have hindered the victim's capacity to reason and decide at the moment of killing himself. Therefore, the latter verdict represented the first possibility of linking suicide with insanity, either mental or physical, from a legal perspective (ibid.).

Consequently, verdicts of 'non compos mentis' meant that penalties applied to the condemned guilty party, that is the deceased and his family, did not apply. In England, these penalties implied the forfeit of the deceased's goods to the crown or landlord and a profane burial in a crossroad accompanied by a macabre ceremony on the corpse (Fleming, 1773). This could drive the heirs to pauperism and therefore they, together with parishes, often concealed the real nature of the death or invented stories in order to allow the verdict of 'non compos mentis' (MacDonald \& Murphy, 1990; Barbagli, 2009; Marsh, 2010). The resistance to forfeiture proceeded more rapidly than the secularization of suicide verdicts, and the records of the Court of King's Bench report a drop in the forfeited goods of suicide victims at the end of the 17 th century. In the $1660 \mathrm{~s}, 36 \%$ of suicide victims had their goods forfeited whereas 50 years later, between 1710 and 1720, the percentage dropped to a mere 7.7\% (MacDonald \& Murphy, 1990).

At the beginning of the 16th century, in order to acquit suicide victims of self-murder and save their goods from forfeiture, English juries began to return 'mixed' and 'ambiguous' verdicts along with verdicts of non compos mentis. Non compos mentis verdicts gradually rose from the beginning of the 17th to the beginning of the 19th century when $90 \%$ of suicides were judged as non compos mentis (Fig. 1), thus mirroring an important change in the attitude towards suicide victims that led to the end of what was defined as 'the age of severity' (MacDonald \& Murphy, 1990).

However, co-existing different explanations can be found much earlier. Herodotus recorded the case of the Spartan king Cleomenes I whose suicide was considered either as a divine retribution for his acts of impiety or the result of a madness caused by excessive wine drinking (Preti \& Miotto, 2005). Moreover, documents dating back to the early 16th century reported the beginning of medical and rational approaches to suicide alongside supernatural ones (Table 2) which, however, was not well accepted by everyone (Table 2). 


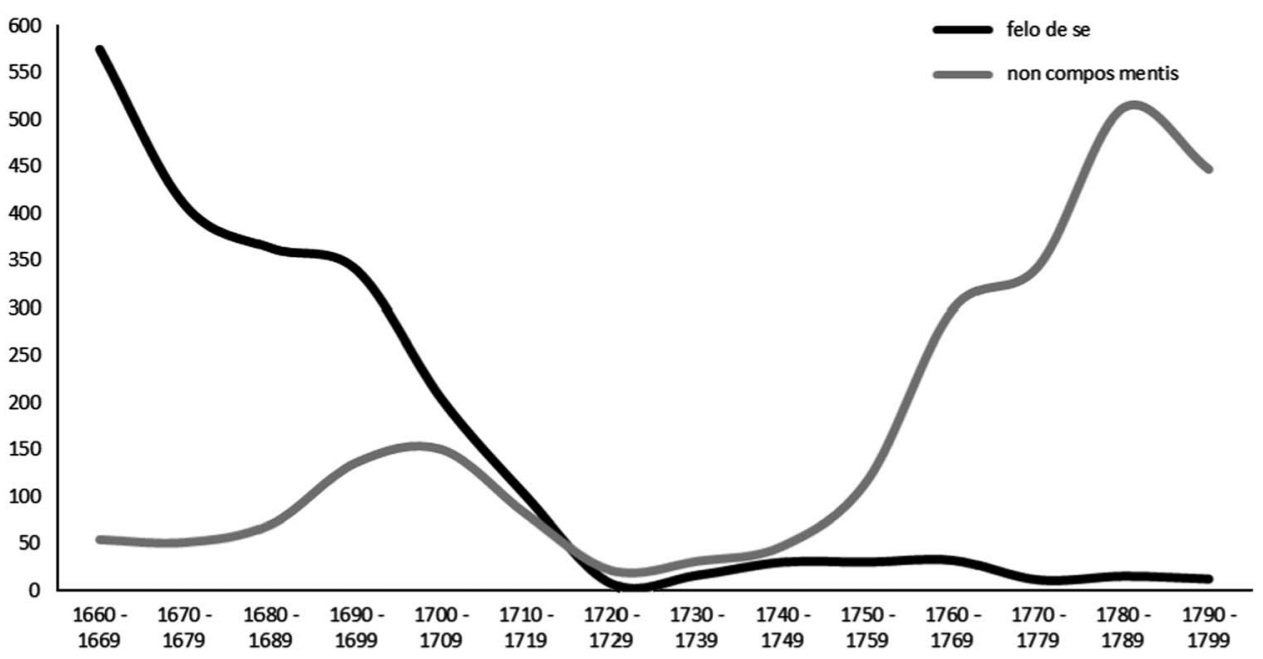

Fig. 1. Verdicts of reported suicides in England, 1660-1799 (Source: MacDonald \& Murphy, 1990).

Table 2. From crime against society to medical illness

The beginning of the changing attitude already

Difficulties in changing the attitude across Europe

In 1502 the Flemish prior Gaspar Ofhuys, who was also the doctor of the monastery, wrote about the suicide of the famous Flemish painter Hugo van der Goes who belonged to his monastery. Ofhuys offered three different understandings of that act: a traditional Christian one which hypothesized a demonic possession of van der Goes; a supernatural one involving the Divine Providence which would have stopped through suicide the ambitiousness of the famous painter-monk and a third one in which the prior hypothesized suicide would have been caused by the ingestion of 'melanchonic foods' which would have altered the equilibrium of body humors (Dolev, 1999)

In 1682 a German book-seller after having attempted suicide, asked for help both to the parish and to the doctor (Lind, 2004)
In 1842 the parish of a French village wrote to the bishop of Angers because a young leper woman had committed suicide. The parish believed the woman was mentally insane whereas her family and other people of the village maintained she was sane and asked for a felo de se verdict despite his mind (Kselman, 1988)
In 1893 a woman in a Russian village drowned herself in a river. Her husband asked for a Christian burial which was allowed despite the strong opposition of the peasants who lived in that village. Some months after her burial some sudden deaths took place in the village which were interpreted by the villagers as a divine punishment for the woman's Christian burial. So her corpse was removed from the graveyard, mutilated and buried in a not-sacred place (Morrisey, 2006)
Eventually, all suicides were considered as resulting from a mental disorder and suicide itself started to be considered as a sign of insanity (Chevalier, 1824; Winslow, 1840). This new understanding paved the way for the medicalization of suicide, which then became something 'doctors had the right to guard, treat, control and judge' (Hacking, 1990: 65). In 1821, Esquirol's Dictionnaire des sciences médicales defined suicide as a disease or a symptom of a disease, thus to be medically investigated (Esquirol, 1821). Therefore, mental illness - which was recognized as the heart of suicide - was investigated through autopsies that aimed to locate physical lesions which could have determined it. In particular, the brains of suicide victims were carefully dissected in the search for pathological alterations and biological markers that could prompt the victims to suicide. However, no evidence was found to support the existence of pathological anatomy related to suicide (ibid.) even though Burrows maintained that this 'does not disprove the existence of a morbid condition' (Burrows, 1828: 416). Akin to Esquirol's formulations, Burrows suggested 
that emotions, mental and moral faculties could become diseased and different kinds of insanity could arise which later could lead to suicide as the result of a too violent impression upon the brain (Burrows, 1828). Thus, suicide became the result of psychopathology, with the site of pathology either acting to cause disturbance on the whole organism (e.g. faulty reasoning consequent upon a brain lesion), or causing brain lesions (Esquirol, 1821). Thus, the body became the major source of investigation to understand suicide and suicidal individuals were systematically watched and examined in asylums in order to identify some premonitory signs of their propensity to commit suicide. However, the lack of findings of pathological anatomy thwarted the development of 'organic theories' of suicide and Prichard (1835) wrote about the existence of functional disorders of the mind in his Treatise on Insanity and Other Disorders Affecting the Mind.

The influence of the Enlightenment on the overall attitude towards suicide and the concept of human life stemmed from an intellectual querelle which began at the end of the 16th century when philosophers, writers and theologians all over Europe began to wonder about man's right to take his own life, condemning the contemporary Christian conceptualization (Houston, 2010). For instance, during the Englightment period, the understanding of 'Man' and human nature lie upon the idea that human beings are no more than matter organized in such a way that it gives sensations. Consequently, experiences shape and determine the way the mind develops and the moral and intellectual faculties of mankind are grounded in sensorial experiences (Locke, 1690). From this perspective, the first intellectuals who engaged in the querelle on suicide included Thomas More (2015) who defended some forms of suicide in Utopia in 1516, John Donne (2010) who put forward the idea of suicide carried out for the glory of God - such as Jesus Christ's crucifixion - in Biathanathos in 1610 and Montaigne in A custum of the Isle of Cea written in 1580. In particular, Montaigne wrote: '[death] neither is it a recipe for one disease only; death is the infallible cure of all; 'tis a most assured port that is never to be feared, and very often to be sought. It comes all to one, whether a man give himself his end, or stays to receive it by some other means [...]. The most voluntary death is the finest. Life depends upon the pleasure of others; death upon our own. [...] Reputation is not concerned in such an enterprise; 'tis folly to be concerned by any such apprehension. Living is slavery if the liberty of dying be wanting. [...] The ordinary method of cure is carried on at the expense of life; they torment us with caustics, incisions, and amputations of limbs ... Why is not the jugular vein as much at our disposal as the median vein?' (Montaigne, 1910: 12-13).
In the 18th century Montesquieu, Cesare Beccaria and Voltaire further developed the thesis of man's right to commit suicide since life itself was a man's own property and human beings were unique and had the right to self-realization and to the pursuit of happiness in life. Beccaria and Voltaire in particular were engaged in the struggle to reform the penal system for the decriminalization of suicide. In the wake of the Enlightenment, new intellectual theories were developed including Contractualism, Utilitarianism and neo-epicurean understandings of life. For instance, according to Contractualism, society was a contract stipulated among subjects from which everyone had the right to step back through suicide whenever it became no longer convenient. Utilitarianism grounds its understandings of life on happiness and consequentialism whereby everything is good if it is useful for happiness and actions must be judged for their consequences on the happiness of society. Therefore, subjects could take their life both for the sake of their own happiness and the good of the others. Similarly, Neo-Epicurean understandings envisage man's main goal in life as pursuing pleasure and rejecting pain. Consequently, life can be stopped when not deemed pleasant anymore.

In the 19th century, as Romanticism spread, the attitude towards suicide changed even further. The rational approach that had characterized the Enlightenment was replaced by a passionate and idealized view of suicide that was celebrated by many famous writers throughout Europe such as Goethe, Schiller and Tolstoj. Under the influence of masterpieces like The sorrows of young Werther, Anna Karenina and The Last Letters of Jacopo Ortis, a rapid increase in the number of suicides occurred and was defined as a new fashion by Tissot in 1840 in his The mania of suicide and the spirit of revolt, their causes and remedies. However, at the end of the 19 th century Durkheim (1897) developed his theory of suicide in Suicide, A Study in Sociology according to which society played a pivotal role in determining it. Durkheim suggested that man was modeled by society and social rules inevitably stemmed from the individual ones and then became superior to them through the process of being shared and becoming a common value. Durkheim claimed that subjects were ruled by society and suggested a double identity for man: the first being an identity at the individual level and the second as part of society. Suicide, according to Durkheim, is the result of the disruption of the subject's social integration related to various factors and he acknowledges four kinds of suicide, namely altruistic, egoistic, fatalistic and anomic suicide (Durkheim, 1897). For instance, egoistic suicide reflects a deep sense of not belonging and nonintegration in the community that determines the 
subject being left with little social support or guidance and is therefore more likely to commit suicide. Altruistic suicide is the opposite of egoistic suicide and, according to Durkheim, occurs in highly integrated societies when the individual is expected to kill himself on behalf of the society. Fatalistic suicide occurs in excessively rigid societies which are so oppressive that their inhabitants would rather die than live on. Ultimately, anomic suicide reflects an individual's moral confusion and lack of social direction which is related to dramatic social and economic upheavals as well as downturns. Durkheim explains that anomie is a state of moral disorder where people do not know their limits and are constantly in a state of disappointment. In conclusion, Durkheim's four types of suicide are based upon the degrees of imbalance of two social forces: social integration and moral regulation (Thompson, 1982).

\section{A new conceptualization of suicide within economies of power: the Durkheim influence}

Durkheim's structural approach to suicide together with his sociological theories led to the development of a complex conceptualization of suicide that implied a three-level analysis of the act. The over-structural level considered social and political ideologies and religion; the structural level included social class, communities and economic and political aspects; the understructural level in which individual and social psychological aspects were considered. None of them could stand alone, but each of them had to be analyzed for the whole understanding of the phenomenon.

To gain a deeper understanding of the sociological processes described above which led to a change in the conceptualization of suicide, Foucault's concept of differing 'economies of power' (1981: 135) could be helpful. According to Foucault's analysis, there were two contrasting 'economies of power' (p. 135) namely 'sovereign power' and 'bio-power.' The former referred to the privilege of sovereigns to dispose of their subjects' life, they could either 'take their life or let them live' (Foucault, 1981: 136). According to the 'sovereignpower' perspective, when suicide was committed the victim had stolen his own life and the right to decide over it from the sovereign and consequently had to be punished and to pay back for this crime with the confiscation of goods and the denial of a Christian burial. In the 17th and 18th centuries, a shift within society occurred and the exercise of power became an effort to reinforce, control, optimize and organize life-generating forces rather than submitting to and impeding them. This new form of power, called by Foucault 'bio-power,' was situated and exercised by society, that is at the level of life rather being somehow above it exercised by a sovereign or God (Rabinow \& Rose, 2003). Its main aim was to foster life and maximize the potentialities of both the individual body and the body of the population, thus creating an 'anatomopolitics of the human body' (Foucault, 2002: 138) alongside a 'biopolitics of the population' (ibid.: p. 139). Suicide, in this bio-political field, could become the target of management at both population and individual level. In this setting, suicide became a failure of society and led to the recognition of suicide as a problem, which had to be further investigated and better understood.

However, in both 'economies of power' the subject was the focus of some form of pressure and control exerted by the society in which he/she lives (i.e. the subject played a passive role and was somehow shaped by society).

Since the early 19th century suicidal people were confined to asylums and the French and British began keeping track of suicides in order to expand the body of knowledge of this phenomenon (Hacking, 1990). These changes may have resulted from this new bio-political rationality and represent the forerunners of modern-day epidemiological studies and treatment strategies (Marsh, 2010). The problematization of suicide - which was not acknowledged as an inevitable death - led to many studies, which allowed a deeper understanding of suicide in its various aspects. In the 20th century, 'suicidology,' that is a discipline of the scientific study of suicide (Maris et al. 2000), was developed. Since suicide is a complex phenomenon, suicidology involves many different fields and disciplines, the two primary ones being psychology and sociology (Shneidman, 2001).

\section{Suicide and economic factors: some socio-economic understandings from the past}

Historians and sociologists investigated the effect of economic cycles on suicide rates, which to date remains uncertain (Stuckler et al. 2011). A large stream of empirical studies support the influence of unemployment on suicide rates in Europe (ibid.), suggesting an increase of unemployment by $1 \%$ point would lead to an increase by $0.09 \%$ point of suicide rate (per 100000 inhabitants) (Breuer, 2015). This would peak by $0.21 \%$ point considering men in working age (ibid.), though other studies do not confirm the existence of this influence (Andres, 2005; Polyzos, 2012; Fountoulakis et al. 2013). Considering other economic parameters, an increase in gross domestic product per capita and gross value added negative correlated with suicide rates in Europe (Breuer, 2015). An Italian study investigating the relationship between inflation, employment status and suicidal behavior in a stratified sample showed that the unemployed were at higher suicide risk than 
the employed and in particular, this was higher in the unemployed who had been previously employed (Solano et al. 2012). The change in social status caused by the job-loss would have determined a further vulnerability to inflation in this sample compared with the unemployed who never worked and those employed (Solano et al. 2012). These recent studies show a complex interplay of socio-economic factors influencing suicidal behaviors - which is still an open question. Therefore, we aimed to review and discuss some sociological theories involving economic factors together with factors related to mental illness, which we believe should be carefully considered when discussing suicide.

From an economic point of view, when the terrors of death are less than the terrors of life, the cost/benefit equation increases suicide risk in every society and time (Stack, 2000). People under high economic strain, such as the poor, face greater anxieties, isolation and distress. Nowadays, social support systems such as financial, companionship and emotional support programmes play a pivotal role in lowering suicide rates (Zimmerman, 1987a, 1987b, 1990, 2002; Yur'yev, 2012).

For instance, among the unemployed the prevalence of psychological problems is twice as high as in employed people (Paul \& Moser, 2009) and unemployment had a lower impact in countries with strong employment protection. Conversely, lesser unemployment protection coupled with sharper increase in unemployment yield a strong unemployment effect on suicide (Norström \& Grönqvist, 2015). Consequently, unemployment protection modifies the impact of unemployment on suicide rates. However, the scarce development of social support networks of any kind in the past, when the welfare state had yet to be developed in Europe, should be carefully taken into account when considering suicide and economic regressions in the past (Yur'yev, 2012).

The economic uncertainty of the 17th and 18th centuries (Hoppit, 1986), that historians claim to be related to the rise of suicide rates, may be partly understood, we believe, in the light of Durkheim's (1897) 'anomic suicide' (ibid.: p. 241). This occurs when a man goes through rapid extreme changes in wealth including both economic ruin and windfall gains. In both cases the previous life style together with its expectations and limits are subverted. This leads to the need of finding new identities and stability before the subject can judge his new situation in relation to its new limits. Thus, a rapid economic and social upheaval might cause a state of anomie regardless of the direction of the change (ibid.). For instance, the lack of definition that is typical of economic uncertainty is reflected both in stock market behavior and suicide rates (Pierce, 1967). Durkheim (1897) reported through the conceptualization of anomie - that is, of unintegration - the $51 \%$ increase in suicide rates that occurred in Vienna from 1872 to 1874 during the economic crisis. During upheavals, society abruptly loses its normative and limiting function that regulates and shapes the subject's desires and needs from birth, causing a state of confusion in which the subject loses the perception of his role in society and is exposed to dysregulations leading to suicide. For instance, uncertainty and instability dominated the impressions of life in the 18th century England during which harvest fluctuations or depressions in trade and fiscal crises could abruptly upset the welfare of the family (George, 1951). More than 13 periods of financial crises are reported in the 18th century in England and among them the bursting of the South Sea Bubble was presumably the greatest one which caused an almost doubling of suicides in London the year after the crash (Hoppit, 1986) and the General Bills of Mortality 1660-1800 reported a period of high rates of suicides in the following two decades (MacDonald \& Murphy, 1990). Wealth and happiness were closely bound in the mind of 17th-18th century men; the suicide of a wealthy man was reported by the newspapers of the time only as something understandable as an act deriving from insanity (MacDonald \& Murphy, 1990). Data from the King's Bench showed how the majority of suicide victims with a verdict of felo de se reported by coroners between 1485 and 1714 had a humble social status (Fig. 2), this, however, could result from the need of wealthy people to save their goods from forfeiture thus needing a non compos mentis verdict (Houston, 2010).

However, the fact that the majority of victims belonged to humble social classes, independently from the assigned verdict, may also be due to mental illness in relation to poverty. For instance, evidence showed controversial relationships between poverty and mental disorders reporting both the hypothesis that mental illness may favor poverty and that, according to social causational understandings, poverty may promote mental disorders (Costello et al. 2003; Gadalla, 2009). This is consistent with Halbwachs's conceptualizations (1930) that underlined the importance of isolation in causing suicide and maintained that suicide should be understood as resulting from the complex interplay of both socio-economic and psychological factors.

Furthermore, Henry \& Short (1954) suggested that suicide is an act of aggression and linked it with frustration, that is an economic crisis is associated with a high degree of frustration due to changes in hierarchical positions that together with external restrictions and disappointment of expectations cause suicide. However, not all studies supported Henry and Short's theory and few of them confirmed Durkheim's suggestion of a relationship between integration, 


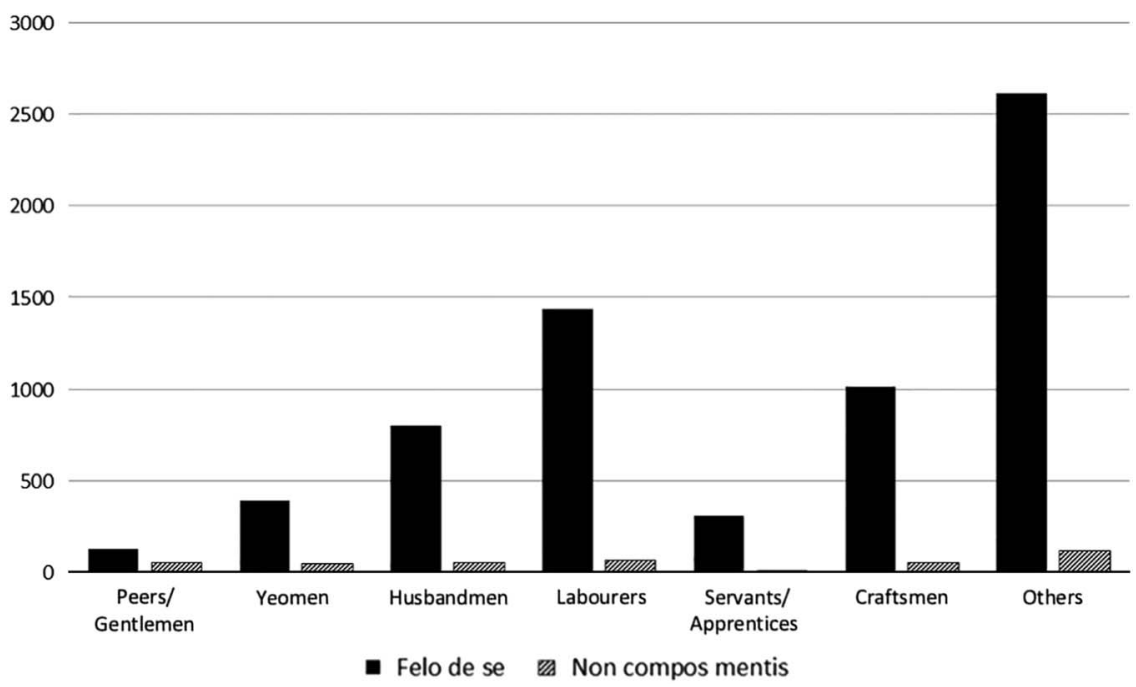

Fig. 2. Social status and verdicts of suicides in England 1485-1714. These, however, are absolute data and do not consider the different representation of social classes within the population (Source: Public Record Office, adapted from MacDonald \& Murphy, 1990).

regulations and suicide when analyzing national suicide rates (Lester, 1968, 1992).

Gibbs \& Martin further developed the Durkheimian approach by suggesting the notion of 'status integration' (1958: 140), that is, the integration of the different roles the individual occupies at the same time in society. Suicide could be caused by the simultaneous presence of incompatible statuses and their sudden change, as occurs in an economic crisis. Thus, macro and micro economy are intertwined in influencing suicidal behaviors.

Hamermesh \& Soss (1974) were the first to develop an economic theory for suicide in which living conditions, such as income, status and unemployment would explain suicidal behavior and supported it providing empirical data. They postulated the existence of a direct relationship between certain economic factors both pecuniary and non - such as permanent income and discounted lifetime utility, that is the individual's perceived happiness for both present and future - and the likelihood of suicide by a certain subject. According to this economic theory of suicide an individual (i) at age (a) with a permanent income $(Y)$ takes his own life when the total discounted lifetime utility $\left(Z_{i}\right)$ plus the individual's taste for living, that is the distaste for suicide, $\left(b_{i}\right)$ reaches zero.

$$
Z_{i}(a, Y)+b_{i}=0
$$

with

$$
Z_{t}(a, Y)=\int_{a}^{\omega} e^{-r(m-a)} U_{m} P(m) d m
$$

where $\omega$ denotes the highest attainable age, $r$ the discount rate and $U m$ the expected utility at age $m . P m$ is the probability of survival to age $m$ given survival to age $a$. In addition to its negative relationship with the age $m$, the individual's expected utility $U m$ is positively related to the permanent income $Y$. The individual's taste for living $b_{i}$ is assumed to be normally distributed so that the ageadjusted aggregate suicide rate, defined as the fraction of individuals in the age group $a$ for whom $Z(a, Y)$ reaches $b$, is inversely related to the permanent income $\mathrm{Y}$. Therefore, the economic theory of suicide suggests that the increase in income pro capita leads to a reduction of the likelihood of suicide (Hamermesh \& Soss, 1974).

Though suicide derives from the intertwining of different factors, the economic theory of suicide is noteworthy since it represents the first attempt by economists to investigate suicide from their point of view.

\section{Limitations}

This study has a historical basis and reviews major sociological and economic theories of suicide developed in the past. Consequently, the resulting understandings fit the society in which they were developed. Therefore, their application to the current situation has to be carefully evaluated each time because sociological and economic factors, as well as human understanding, vary in time. Further limitations of this study may derive from the fact that historical papers provide extensive and accurate theoretical understandings but there are few research studies reporting reliable data because of the lack of register-based recording strategies of suicides in the past. Therefore, reported data may underestimate the phenomenon and concern limited samples or isolated cases. Moreover, reliable studies were not equally available for the different 
historical times and, therefore, in each case the body of evidence varied considerably in size. Thus, the accuracy of our understandings may vary accordingly.

\section{Conclusion}

In this paper, we provided different views of past conceptualizations of suicide concerning both its social value and its interplay with economic factors and how this changed throughout time. Suicide is a complex and difficult-to-explain phenomenon for which many hypotheses and theories have been suggested, though no definitive one has been found yet. 'Struggling to make sense of a phenomenon is something about which we can do a great deal' (Berman, 2012) and we believe that keeping in mind the past could provide a valuable background for a deeper understanding of the present. For instance, this could lead to the development of more effective prevention strategies, such as better social support structures that carefully take into account man's sense of self, the conceptualization of his own identity within the particular society he lives in characterized by its economy of power. Beyond tangible support strategies, the empowerment of non-financial social supportive resources are required. When planning international suicide prevention strategies, emotional (nurturance), informational (advice) or companionship (sense of belonging) and intangible (personal advice) services should be developed. These target different aspects of human life, such as the individual's sense of belonging both to the macro and micro community (family), cohesion and self-directedness. Furthermore, drawing on the understandings concerning the development of current conceptualizations of suicide, ad hoc informative support should be provided and encompass multi-layered analysis of the perception of suicide and suicidality in order to effectively reach the suicidal population. Finally, the structure of current societies should be thoroughly examined in order to identify and challenge potential gaps that may promote suicidal desires and acts. This includes deeper awareness of the importance of social support programmes in times of uncertainties - especially for the poor. We believe this to be of paramount importance in a time of marked cuts in public expenditure, leading to the reduction of social support programmes and a possible resultant strain on the most vulnerable in society. Keeping in mind and learning from the history and complex development of the current conceptualization of suicidal phenomena provides us with thorough and deeper understandings that may help to better comprehend and deal with suicide nowadays.

\section{Acknowledgments}

The authors would like to express their gratitude to Dr C. Stark for her fine work of English revision.

\section{Financial Support}

This research received no specific grant from any funding agency, commercial or not-for- profit sectors.

\section{Conflicts of Interest}

All authors declare that they have no conflicts of interest.

\section{Ethical Standards}

The Authors assert that all procedures contributing to this work comply with the ethical standards of the relevant national and institutional committee on human experimentation with the Helsinki Declaration of 1975 , as revised in 2008 .

\section{References}

Alvarez A (2002). The savage God: a study of suicide. Bloomsbury Publishing: New York.

Andres AR (2005). Income inequality, unemployment, and suicide: a panel data analysis of 15 European countries. Applied Economics 37, 439-451.

Aquinas T (2006). Summa Theologiae: Volume 38. Cambridge University Press: Cambridge.

Augustine of Hippo (2008). The City of God. Hendrickson Publishers: New York.

Barbagli M (2009). Congedarsi dal mondo [Leaving the world]. Il Mulino: Milan.

Berman L (2012). News bulletin, IASP. October-November 2012.

Breuer C (2015). Unemployment and suicide mortality: evidence from regional panel data in Europe. Health economics 24, 936-950.

Brown RM (2001). The Art of Suicide. Reaction Books: London.

Burrows J (1828). Commentaries on the Causes, Forms, Symptoms and Treatment, Moral and Medical, of Insanity. Thomas and George Underwood.: London.

Catholic Church (1992). Catechism of the Catholic Church. Libreria Editrice Vaticana: Vatican State.

Chevalier T (1824). Remarks on suicide. The Pampheleteer 23, 365-373.

Churchill LR (1994). Physician-assisted suicide. Journal of the Royal Society of Medicine 87, 44-46.

Colucci E, Martin G (2008). Religion and spirituality along the suicidal path. Suicide and Life-Threatening Behavior 38, 229-244.

Costello EJ, Compton SN, Keeler G, Angold A (2003). Relationships between poverty and psychopathology: a natural experiment. JAMA 290, 2023-2029.

Crone DM (1996). Historical attitudes toward suicide. Duquesne Law Review 35, 7-42.

De Vogli R, Marmot M, Stuckler D (2013). Excess suicides and attempted suicides in Italy attributable to the great recession. Journal of Epidemiology and Community Health 67, 378-379. 
Dolev N (1999). Gaspar Ofhuys' Chronicle and Hugo van der Goes. Assaph: Publication of the Tel-Aviv University, Faculty of Fine Arts. Studies in art history 4, 125.

Donne J (2010). Biathanatos: A Declaration of That Paradox or Thesis That Self-Homicide Is Not So Naturally Sin, That It May Never Be Otherwise. Kessinger: New York.

Durkheim E (1897). Suicide, A Study in Sociology. Free Press: New York.

Economou M, Madianos M, Peppou LE, Theleritis C, Stefanis CN (2012). Suicidality and the economic crisis in Greece. The Lancet 380, 337.

Esquirol J (1821). Suicide. In Dictionnaire des Sciences Médicales: par une societé des medécins et des chirurgiciens, Vol. LIII. (ed. BIU Santé), Panckouke: Paris.

Farberow NL (1975). Suicide in Different Cultures. University Park Press: New York.

Fleming C (1773). A Dissertation Upon the Unnatural Crime of Self-Murder. Dilly: London.

Foucault M (1981). The History of Sexuality (Vol. I, An Introduction (Trans. Hurley R Harmondsworth) Penguin: London.

Foucault M (2002). The Essential Works of Foucault 1954-1984, Vol. III: Power. Penguin: London.

Fountoulakis KN, Koupidis SA, Siamouli M, Grammatikopoulos IA, Theodorakis PN (2013). Suicide, recession, and unemployment. The Lancet 381, 721-722.

Gadalla TM (2009). Determinants, correlates and mediators of psychological distress: a longitudinal study. Social Science and Medicine 68, 2199-2205.

George MD (1951). London Life in the Eighteenth Century. Routledge: London.

Gibbs JP, Martin WT (1958). A theory of status integration and its relationship to suicide. American Sociological Review 23, 140-147.

Hacking I (1990). The Taming of Chance. Cambridge University Press: Cambridge.

Halbwachs M (1930). Les causes du suicide. Alcan: Paris.

Hamermesh DS, Soss NM (1974). An economic theory of suicide. Journal of Political Economy 82, 83-98.

Hawton K, Van Heeringen K (2009). Suicide. The Lancet 373, 1372-1381.

Healy R (2006). Suicide in early modern and modern Europe. Historical Journal 49, 903-919.

Henry AF, Short JF (1954). Suicide and Homicide: Some Economic, Sociological and Psychological Aspects of Aggression (Vol. 91442) Free Press: New York.

Hill TD (2004). Ambitiosa Mors: Suicide and the Self in Roman Thought and Literature. Routledge: London.

Hoppit J (1986). Financial crises in eighteenth-century England. Economic History Review 39, 39-58.

Houston RA (2010). Punishing the Dead?: Suicide, Lordship, and Community in Britain, 1500-1830. Oxford University Press: Oxford.

Innamorati M, Pompili M, Lester D (2012). Economic crises and suicide. In Suicide: A Global Perspective ((ed. M. Pompili), pp. 30-39. Bentham Science: New York.

Karanikolos M, Mladovsky P, Cylus J, Thomson S, Basu S, Stuckler D, McKee M (2013). Financial crisis, austerity, and health in Europe. The Lancet 381, 1323-1331.
Kentikelenis A, Karanikolos M, Reeves A, McKee M, Stuckler D (2014). Greece's health crisis: from austerity to denialism. The Lancet 383, 748-753.

Kovacs D (2002). Volume V. Helen: Phoenician Women. Orestes. Loeb Classical Library, Harvard University Press: Cambridge, MA.

Kselman T (1988). Funeral conflicts in the nineteenthcentury France. Comparative Studies in Sociology and History 30, 312-333.

Lester D (1968). Henry and Short on suicide: a critique. Journal of Psychology 70, 179-186.

Lester D (1992). A test of Durkheim's theory of suicide in primitive societies. Suicide and Life-Threatening Behavior 22, 388-395.

Lind V (2004). Suicidal mind and body. Example from Northern Germany. In From Sin to Insanity (ed. J. R. Watt), pp. 64-81. Cornell University Press: New York.

Lloyd-Jones H (1994). Ajax, Electra, Oedipus Tyrannus. Loeb Classical Library, Harvard University Press: Cambridge, MA.

Locke J (1690). Essay Concerning Human Understanding (eds. Tegg and Son). Studies in Philosophy: Dublin.

Lundin A, Lundberg I, Hallsten L (2010). Unemployment and mortality - a longitudinal prospective study on selection and causation in 49321 Swedish middle-aged men. Journal of Epidemiology and Community Health 64, 22-28.

Luo F, Florence C, Quispe-Agnoli M, Ouyang L, Crosby A (2011). Impact of business cycles on US suicide rates, 1928-2007. American Journal of Public Health 101, 1139-1146.

MacDonald M (1995). Suicidal behavior-social section. In $A$ History of Clinical Psychiatry (eds. G.E. Berrios and R. Porter), Athlone Press: London.

MacDonald M, Murphy TR (1990). Sleepless Souls: Suicide in Early Modern England. Oxford University Press: Oxford.

Maris RW, Berman A, Silverman M (2000). Comprehensive Textbook of Suicidology. The Guilford Press: New York.

Marsh I (2010). Suicide: Foucault, History and Truth. Cambridge University Press: Cambridge.

Martin R, Barresi J (2006). Rise and Fall of Soul and Self: An Intellectual History of Personal Identity. Columbia University Press: New York.

McCormack R, Clifford M, Conroy M (2012). Attitudes of UK doctors towards euthanasia and physician-assisted suicide: a systematic literature review. Palliative Medicine 26, 23-33.

Montaigne M (1910). Essays of Montaigne Vol. IV Edwin Hill: New York.

More T (2015). Utopia. Penguin: London.

Morrisey SK (2006). Suicide and the Body Politics in Imperial Russia. Cambridge University Press: Cambridge.

Murray A (1998). Suicide in the Middle Ages, Vol. I, The Violent Against Themselves. Oxford University Press: Oxford.

Neumayer E (2004). Recessions lower (some) mortality rates: evidence from Germany. Social, Science and Medicine 58, 1037-1047.

Norström T, Grönqvist H (2015). The great recession, unemployment and suicide. Journal of Epidemiology and Community Health 69, 110-116.

Paul K, Moser K (2009). Unemployment impairs mental health: meta-analyses. Journal of Vocational Behavior 74, 264-282. 
Pierce A (1967). The economic cycle and the social suicide rate. American Sociological Review 32, 457-462.

Polyzos N (2012). Health and the financial crisis in Greece Health and the financial crisis in Greece. The Lancet 379, 1000-1011.

Pompili M, Innamorati M, Vichi M, Masocco M, Vanacore N, Lester D, Serafini G, Tatarelli R, De Leo D, Girardi P (2011). Inequalities and impact of socioeconomic-cultural factors in suicide rates across Italy. Crisis 32, 178-185.

Preti A, Miotto P (2005). Suicide in classical mythology: cues for prevention. Acta Psychiatrica Scandinavica 111, 384-391.

Prichard JC (1835). A Treatise On Insanity and Other Disorders Affecting the Mind. Arno Press: New York.

Rabinow P, Rose N (2003). The Essential Foucault. The New York Press: New York.

Rosen G (1971). History in the study of suicide. Psychological Medicine 1, 267-285.

Royal D (1850). On suicide—verdicts of Felo-de-se. Journal of Psychological Medicine and Mental Pathology 1, 19-30.

Seabourne A, Seabourne G (2001). Suicide or accident - selfkilling in medieval England: series of 198 cases from the Eyre records. British Journal of Psychiatry 178, 42-47.

Segal DL, Mincic MS, Coolidge FL, O'Riley AL (2004). Attitudes toward suicide and suicidal risk among younger and older persons. Death Studies 28, 671-678.

Shneidman ES (1985). Definition of Suicide. John Wiley \& Sons: New York.

Shneidman ES (2001). Comprehending Suicide Landmarks in 20th-Century Suicidology. American Psychological Association: Washington.

Solano P, Pizzorno E, Gallina AM, Mattei C, Gabrielli F, Kayman J (2012). Employment status, inflation and suicidal behavior: an analysis of a stratified sample in Italy. International Journal of Social Psychiatry 58, 471-484.
Stack S (2000). Suicide: a 15-year review of the sociological literature. Part I: cultural and economic factors. Suicide and Life-Threat Behavior 30, 145-162.

Stack S, Kposowa AJ (2011). Religion and suicide acceptability: a cross-national analysis. Journal for the Scientific Study of Religion 50, 289-306.

Strozier RM (2002). Foucault, Subjectivity, and Identity: Historical Constructions of Subject and Self. Wayne State University Press: Detroit.

Stuckler D, Basu S, Suhrcke M, Coutts A, McKee M (2009). The public health effect of economic crises and alternative policy responses in Europe: an empirical analysis. The Lancet 374, 315-323.

Stuckler D, Basu S, Suhrcke M, Coutts A, McKee M (2011). Effects of the 2008 recession on health: a first look at European data. The Lancet 378, 124-125.

Taylor C (1989). Sources of the Self: The Making of the Modern Identity. Harvard University Press: Cambridge, MA.

Thompson K (1982). Emile Durkheim. Tavistock Publications: London.

Winslow B (1840). The Anatomy of Suicide. Henry Renshaw: London.

Yur'yev A, Värnik A, Värnik P, Sisask M, Leppik L (2012). Role of social welfare in European suicide prevention. International Journal of Social Welfare 21, 26-33.

Zimmerman SL (1987a). States' public welfare expenditures as predictors of state suicide rates. Suicide and Life Threatening Behaviors 17, 271-287.

Zimmerman SL (1987b). State-level public policy as a predictor of individual and family well-being. Women Health 12, 161-188.

Zimmerman SL (1990). The connection between macro and micro levels: states' spending for hospitals and their suicide rates. Suicide and Life Threatening Behaviors 20, 31-55.

Zimmerman SL (2002). States' spending for public welfare and their suicide rates, 1960 to 1995: what is the problem? Journal of Nervous and Mental Disease 190, 349-360. 